\title{
Study of dynamics of electro-chemical properties of submerged soils
}

\section{RAGHAVENDRA REDDY, LOKESH PATIL, P. N. SIVA PRASAD, G. S. YOGESH AND H.C. PRAKASHA}

Received : 15.01.2016; Revised : 24.03.2016; Accepted : 20.04.2016

\section{MEMBERS OF RESEARCH FORUM:}

Corresponding author : M. RAGHAVENDRA REDDY,

Department of Soil Science and Agricultural Chemistry, University of Agricultural Sciences (G.K.V.K.), BENGALURU (KARNATAKA) INDIA

Co-authors :

LOKESH PATIL, P.N. SIVA PRASAD, G.S. YOGESH AND H.C. PRAKASHA, Department of Soil Science and Agricultural Chemistry, University of Agricultural Sciences (G.K.V.K.), BENGALURU (KARNATAKA) INDIA Email: yogi9660@ gmail.com

\section{Summary}

Wetland rice systems in Asia make a major contribution to global rice supply. The system is also able to maintain soil fertility on a sustainable basis. The essential components of wetland rice culture comprise cultivation of land in the flooding, puddling and transplanting of rice seedlings into puddled rice paddies, and growing the rice crop under flooding. The wetland rice system, growing rice in submerged soils has a great ameliorative effect on chemical fertility: largely by bringing $\mathrm{pH}$ in the neutral range, resulting in better availability of plant nutrients and accumulation of organic matter. Submergence bring a lot changes in redox potential which in turn gives the idea of reduction of nutrients to release to soil solution to make available to plant. This article revealed the dynamic changes of soil $\mathrm{pH}$, electrical conductivity and Redox potential on submergence.

Key words : Flooding, Submergence, Soil pH, Electrical conductivity, Redox potential

How to cite this article : Reddy, M. Raghavendra, Patil, Lokesh, Prasad, P.N. Siva, Yogesh, G.S. and Prakasha, H.C. (2016). Study of dynamics of electro-chemical properties of submerged soils. Asian J. Soil Sci., 11 (1) : 74-77 : DOI : 10.15740/HAS/AJSS/11.1/74-77. 